NBER WORKING PAPER SERIES

\title{
ECONOMIC OPPORTUNITIES AND GENDER DIFFERENCES IN HUMAN CAPITAL: EXPERIMENTAL EVIDENCE FOR INDIA
}

\author{
Robert T. Jensen \\ Working Paper 16021 \\ http://www.nber.org/papers/w16021 \\ NATIONAL BUREAU OF ECONOMIC RESEARCH \\ 1050 Massachusetts Avenue \\ Cambridge, MA 02138
}

May 2010

I would like to thank Dora Costa, Pascaline Dupas, Nolan Miller, Adriana Lleras-Muney, Mai Nguyen, Jeff Nugent, Emily Oster, John Strauss and seminar participants at Berkeley, Columbia, the University of Chicago and Yale for valuable comments and discussions. Financial support from the Center for Aging and Health Research at the National Bureau of Economic Research, the Women and Public Policy Program, the Dean's Research Fund at and the William F. Milton Fund at Harvard University is gratefully acknowledged. I would also like to thank Shubhashis Gangopadhyay and the India Development Foundation for hosting me during the initial stages of this project. The views expressed herein are those of the author and do not necessarily reflect the views of the National Bureau of Economic Research.

NBER working papers are circulated for discussion and comment purposes. They have not been peerreviewed or been subject to the review by the NBER Board of Directors that accompanies official NBER publications.

(C) 2010 by Robert T. Jensen. All rights reserved. Short sections of text, not to exceed two paragraphs, may be quoted without explicit permission provided that full credit, including $\odot$ notice, is given to the source. 
Economic Opportunities and Gender Differences in Human Capital: Experimental Evidence for India

Robert T. Jensen

NBER Working Paper No. 16021

May 2010

JEL No. I0,J16,O12

\begin{abstract}
Gender differences in health and education are a concern for a number of developing countries. While standard theory predicts human capital should respond to market returns, social norms (e.g., disapproval of women working outside the home) may weaken or even sever this link for girls. Though many studies have examined the link between women's wages or labor force participation and investment in girls, two significant problems are the possibility of omitted variables bias and reverse causality, and difficulty in identifying which of several mechanisms (returns, bargaining power, income, etc.) link the two. To overcome these problems, we provided three years of recruiting services to help young women in randomly selected Indian villages get jobs in the business process outsourcing industry. Girls in treatment villages were more likely to be in school and had greater measured BMI. We argue that the design of the experiment (providing opportunities almost exclusively for young, unmarried women rather than current mothers) allows us to rule out that mechanisms other than increases in the returns explain our results.
\end{abstract}

Robert T. Jensen

UCLA School of Public Affairs

3250 School of Public Affairs Building

Box 951656

Los Angeles, CA 90095-1656

and NBER

robertjensen@ucla.edu 


\section{INTRODUCTION}

There has long been considerable concern over the striking gender disparities in human capital outcomes in a number of developing countries, particularly in Asia. For example, in India, the female adult literacy rate is only $48 \%$, compared to $73 \%$ for men. And mortality rates in infancy and childhood are 40-50\% greater for girls than boys, primarily due to inadequate provision of nutrition and medical care (Chen, Huq and D'Souza 1981, Sen and Sengupta 1983, Das Gupta 1987 and Behrman et al. 1988). ${ }^{1}$ The excess mortality of girls contributes to the problem of highly masculine sex ratios and "missing women" that has received considerable attention (Visaria 1969, Miller 1981, Sen 1990).

A number of studies have focused on the returns to human capital or the potential economic contributions of women, particularly in agriculture, as an explanation for these gender disparities (Boserup 1970, Bardhan 1974, Miller 1981, Rosenzweig and Schultz 1982, Foster and Rosenzweig 2009). In varying forms, this argument suggests that human capital investments in girls are lower where the returns are lower. However, in many developing countries, the link between human capital returns and outcomes is more ambiguous than would arise from a simple application of the standard human capital framework, due to cultural practices and norms. For example, Dyson and Moore (1983) and Foster and Rosenzweig (2009) note that the practice of patrilocal exogamy (i.e., marriage between individuals from different villages, with women leaving their birth household to live with their husband's family) means that the returns to investing in girls' human capital do not accrue to parents, leaving them with less incentive to do so. ${ }^{2}$ In addition, in many societies there are strong social prohibitions against women working outside of the home (Boserup 1970, Dube and Palriwala 1990, Field, Jayachandran and Pande 2010, Goldin 1990, 1995 and Mammen and Paxson 2000). In this setting, the social costs to a household of having a woman work may outweigh the potential income gains. Thus, even if parents invested in girls purely for altruistic reasons (rather than for personal gains), girls' schooling would still be insensitive to the market returns if women do not work. This is not to say that parents will not invest in their daughters at all (such as for non-market returns); it is

\footnotetext{
${ }^{1}$ See Strauss and Thomas (1995), Behrman (1997) and Haddad et al. (1997) for reviews.

${ }^{2}$ Though they may still invest in girls for other reasons, such as: altruism; the expectation of transfers from daughters even though they leave the household; or if the marriage market compensates parents for higher human capital daughters (Behrman et al. 1999, Foster and Rosenzweig 2009).
} 
simply that if women do not work, investments in girls should not be affected by changes in the market returns. ${ }^{3}$ In both examples (patrilocal exogamy and social prohibitions against women working), cultural norms or practices can weaken and possibly even sever the link between market returns and investments in girls.

Despite the potential theoretical ambiguity, a large literature has documented that greater female labor force participation or wages are indeed correlated with improved human capital and survival outcomes for girls (Kishor 1993, 1995, Murthi, Guio and Drèze 1995, Agnihotri, Palmer-Jones and Parikh 2002, Rosenzweig and Shultz 1982 and Qian 2008). However, two important factors make it difficult to conclude that it is the increased future earnings potential that leads parents to invest more in their daughters. First, most of these studies use crosssectional data, and concerns about omitted variables bias (areas where women work differ in many ways from areas where women do not work) or reverse causality (higher human capital women are more productive and therefore earn higher wages or are more likely to be in the labor force) make it difficult to draw a causal interpretation from the results, as noted by Sen (1990) and Foster and Rosenzweig (2009). ${ }^{4}$ Three studies that attempt to address these concerns are Rosenzweig and Schultz (1982), who use variation in rainfall as a determinant of women's earnings opportunities, Qian (2008), who exploits a policy reform in China that differentially affected the value of traditionally male and female crops, and Foster and Rosenzweig (2009) who use land prices and yields as measures of expected future technical change and productivity.

Second, most studies cannot specifically identify the mechanism(s) linking current employment rates or wages among adult women to investment in contemporaneously young girls. Beyond expected returns to human capital (i.e., current economic conditions for women reflect returns daughters will face in the future), there are many other potential channels. First, greater earnings opportunities for adult women may increase a mother's bargaining power within the household (Thomas 1990, Schultz 1990; see Strauss and Thomas 1995 and Duflo 2005 for surveys). If women prefer to discriminate less against their daughters than their husbands do, that increased bargaining power could result in greater investments in girls. Second, increases in

\footnotetext{
${ }^{3}$ Behrman et al. (1999) and Foster and Rosenzweig (2009) argue that even if women don't work, their education may respond to market returns due to greater demand (and lower dowries) for more educated wives, who produce higher human capital sons. However, if we increase the potential returns for women only (as in the present case) and women do not work, the marriage market should not respond in this way. ${ }^{4}$ Foster and Rosenzweig (2009) also point out that under patrilocal exogamy, it is the labor market conditions in the villages girls will marry into, not those they are born into, that should matter.
} 
women's employment opportunities, all else equal, increase household income. If investment in girls is a normal or luxury good, then increases in income may benefit girls (Schultz 2001). Third, employment of adult women outside the household may increase the value of daughters, as they substitute for the mother in household production activities such as child care or cooking. This may increase the incentive for parents to invest in their daughters, both just to ensure they survive and can help in the household (Murthi, Guio and Drèze 1995), and because it may make them more productive at those tasks. ${ }^{5}$ Fourth, by raising the opportunity cost of time, women's earnings opportunities may lower fertility, and girls in smaller families may gain more than boys when they compete with fewer siblings for limited family resources. ${ }^{6}$

These mechanisms all yield very different implications for understanding both the root causes of gender bias as well as the policy instruments that will most effectively address the problem. ${ }^{7}$ Yet, most studies cannot identify the underlying mechanism. Qian (2008) provides some arguments that bargaining power of women might explain, at least in part, why increases in the value of women's crops leads to less male-skewed sex ratios in China, but she also notes that it isn't possible to explicitly or directly test this hypothesis against alternatives.

In this paper, we use a randomized intervention in India to ask whether increases in employment opportunities for women lead to greater human capital investments in girls. The Business Process Outsourcing (BPO) industry in India has grown rapidly over the past decade, creating a significant number of new, high-paying opportunities, particularly for women. However, because it was such a new sector, awareness of these jobs and knowledge of how to

\footnotetext{
${ }^{5}$ Of course, the additional time demands of household production could instead lower girls' schooling.

${ }^{6}$ Fifth, if a woman's husband, older children or in-laws take over child care when she enters the labor market, and some of these individuals have lower preferences for discrimination against girls, then women working may lead to gains for girls (women may have stronger reasons to favor sons because they are often forced out of their home or lose their land to their husband's family when he dies unless she has a son (Agarwal 1994, Chen 2000)). Finally, where women have more employment opportunities, they in effect have an insurance mechanism to cope with the unemployment, disability or death of their husbands, as well as a source of income to save for old age and possibly even a pension. If one reason sons are favored in the provision of human capital is that they serve a similar insurance or old age support role for their parents, greater economic opportunities for women weakens the need to do so.

${ }^{7}$ For example, if bargaining power explains the correlation between women's employment and investment in girls, then policies aimed at strengthening women's bargaining power, such as reform or enforcement of divorce laws or strengthening women's property rights, might be favored over efforts to promote women's employment. If it is instead an income effect, then the best policies are those that promote income growth, rather than specifically promoting women's opportunities. Similarly, efforts to directly address fertility or access to old age, unemployment or disability insurance would be favored if those mechanisms are the relevant ones.
} 
access them was very limited, especially outside of the urban core and among less educated households. Our intervention provided three years of BPO recruiting services to women in randomly selected rural villages. By connecting women to experienced recruiters, the intervention was designed to increase awareness of and access to these new opportunities. ${ }^{8}$

Our goal is to test whether the increased employment opportunities for women lead to greater human capital investments in girls. The study offers two key advantages. First, the intervention provided random assignment of potential employment opportunities (or, awareness of and access to these opportunities). This allows us to overcome potentially serious problems of omitted variables bias and reverse causality, and results in a weaker identifying assumption and a stronger case for causality than in the cross-sectional and natural experiment studies listed above.

Second, the intervention allows us to isolate returns as the mechanism linking employment opportunities and human capital investments in our case, eliminating the alternative mechanisms identified above. All of the non-returns mechanisms listed above in effect focus on the impact of employment of current mothers on investments in their daughters, such as a mother having more say over household decisions when she earns a greater share of household income, or changes in the value of the daughter to the household when her mother works. However, our intervention created opportunities primarily for younger, unmarried women, since most employers in this sector strongly favor this group ( $\mathrm{Ng}$ and Mitter 2005) and because most of the jobs require a secondary school degree, English language skills and familiarity with computers, all of which are uncommon among older women. Further, in our project area very few married women, especially those with young children, work outside the household (much less commute long distances or migrate, which would be required for these urban-based jobs), so these opportunities would not apply to them, but instead apply in the future to their daughters. Thus, our experiment enhanced the future returns for currently young girls, leaving the employment opportunities for older women (current mothers) unchanged. This design in effect shuts off all links driven by changes in the employment of current mothers.

Using panel data spanning a three year period, we find that the BPO recruiting and placement services increased employment among young women, with no effect for older women or men of any age (as per the design of the experiment). Girls aged 5-15 in villages that received

\footnotetext{
${ }^{8}$ In this respect, the paper is similar to Jensen (2010), who finds that providing information on the returns to schooling increases educational attainment among boys in the Dominican Republic.
} 
the recruiting services were 3 to 5 percentage points more likely to be in school and experienced an increase in Body Mass Index, reflecting greater nutrition and/or medical care. However, there was no net gain in height. For boys, there was no change in any of these measures.

Three other studies have documented changes similar to those found here. Munshi and Rosenzweig (2006) find that enrollment in English language schools increased for girls (but not boys) in response to increases in the returns to English language education in Bombay, driven principally by the expansion of the financial sector and other white collar industries. More closely related, Oster and Millet (2010) use school-level panel data to show that towns in southern India that saw the introduction of a call center experienced large increases in school enrolment for both boys and girls. Finally, Shastry (2010) finds that the information technology sector grew more rapidly in areas of India where English is more widely spoken, and that in turn those areas experienced increased school enrolment. The results we find are broadly consistent with these other studies. As noted, the key advantages of the present study are the weaker identifying assumption due to randomization, and an intervention that allows us to isolate returns as the mechanism linking the new opportunities for women to investments in girls.

The results have important policy implications. With respect to the significant concern over gender differences in health and education and skewed sex ratios in many low income countries, many authors have suggested that cultural barriers prevent investment in girls, and that change will not be possible without social or cultural change. Correspondingly, most policy efforts have emphasized awareness raising, and information and media strategies to promote the status of girls, i.e., efforts to act on any social or cultural component of bias (Croll 2000). Our results suggest that the labor market plays an important role and that efforts to expand economic opportunities for women can have significant impacts. Our results also provide insight into the underlying causes of poor education and health for both boys and girls more generally in developing countries. Much of the literature has focused on poverty and credit constraints, or "supply side" factors such as distance or access to schools or health clinics, costs, staff training, etc. While these factors are certainly important, since our experiment changed nothing except awareness of the returns to human capital, our results show that there are important "demandside" constraints as well. This suggests that low demand, driven by low returns, may contribute to low human capital attainment in poor countries. 
The remainder of this paper proceeds as follows. Section II discusses the experimental design and Section III discusses the data and empirical strategy. Section IV shows the results and Section V concludes.

\section{EXPERIMENTAL DESIGN}

\section{A. The BPO Sector in India}

The Business Process Outsourcing (BPO) industry is a broad umbrella covering a range of activities and "back office" services. The most highly publicized of these jobs are call centers (e.g., customer service, taking reservations), but the industry is much larger, and also includes data entry and management, claims processing, secretarial services, transcription and online technical support, as well as more skilled activities such as accounting or software development. While the industry has been around in some form for decades, recent technological changes in telecommunications and networking infrastructure (for example, the development and global deployment of fiber optic cable networks) have made it both possible and relatively inexpensive to provide these services remotely to clients around the world. ${ }^{9}$ This in turn lead to dramatic growth in the BPO export sector in many low-wage countries, particularly those like India where English is spoken. BPO growth in India was also facilitated by regulatory changes allowing greater foreign investment in the telecommunications sector. Overall, India's BPO sector experienced 30-40\% average annual growth rates from 2000 to 2008 (NASSCOM 2009).

Within the BPO sector, particularly call centers, there appears to be a preference for female workers. A study of 2,500 call centers in 17 countries found that on average, $69 \%$ of frontline call center workers are women (Holman, Batt and Holtgrewe 2007). Though the rate was closer to $45 \%$ in India, this is still high in comparison to the sex ratio of employment in most other industries. The study reported several reasons employers preferred women, including a more pleasant voice and demeanor when interacting with customers, and the belief that women were more trustworthy than men. ${ }^{10}$

Thus, technological and regulatory changes in the BPO sector in India created a sharp and fairly sudden increase in the demand for female workers, particularly those with secondary

\footnotetext{
${ }^{9}$ Much of the BPO sector is export-driven. For example, in India, almost three-quarters of call centers serve international markets (Holman, Batt and Holtgrewe 2007).

${ }^{10}$ It is also possible that because women have fewer alternative employment opportunities than men, they can be paid less or treated worse, without risk they will leave the job.
} 
school degrees or higher and English language skills. In order to meet this demand, there was a surge in recruiting activities, including through newly-formed, specialized private contractors and subcontractors who would seek out and screen potential employees. And because the BPO sector is strongly geographically concentrated in India, with $95 \%$ of employment focused around seven major cities, recruiting was fairly geographically concentrated as well, leading to large, localized increases in economic opportunities for women.

In general, BPO jobs are fairly well-paid in relative terms. Starting salaries with no experience often ranged from 5,000-10,000 Rupees (Rs.) per month in 2003 (about \$U.S. 110-220, 1 Rs. $\approx 0.022$ \$U.S.), which was about 2-10 times the average starting pay for women outside of the BPO sector. Salaries also often increase rapidly with experience, whereas many other jobs have relatively flat compensation profiles.

\section{B. The Intervention}

Though the BPO sector created a large number of employment opportunities for women, there remained significant gaps in awareness about those jobs and how to access them, precisely because the industry was so new. This was even more pronounced outside the urban centers where these jobs were located (in fact, in our 2003 baseline survey of rural households described below, no one was employed in this sector, including any members or children of members having temporarily or permanently left the household). Our experiment was designed to both increase awareness of these jobs and to make it easier for qualified women to get them.

We hired eight BPO recruiters (5 women and 3 men), all with at least two years experience overall and at least 6 months specifically recruiting women (either working directly for recruiting firms or as freelancers). We drew the recruiters from Delhi, one of the most important cities for the BPO sector. Using maps, the recruiters were asked to identify the specific areas within and outside of Delhi they had visited for recruiting, and then to define the approximate areas outside of Delhi beyond which they believed BPO recruiters would be unlikely to visit due solely to their relative distance from the city and/or their population size. This allowed us to establish a list of where awareness of and access to BPO employment opportunities was likely to be lower, not because there were no qualified women, but simply because the cost per potential recruit was high enough that recruiters chose to visit other areas instead. From this list we drew 80 treatment and 80 control villages at random (most located 
approximately 50-150km from Delhi) from the states of Haryana, Punjab, Rajasthan and Uttar Pradesh. This study region includes much of the area where gender disparities are concentrated in India today. Haryana and Punjab in particular have the most masculine sex ratios in India, and appear to be the only two states where sex ratios continue to worsen rather than improve (Dasgupta, Chung and Shuzhou 2009). And our sample includes some of the districts with the most extreme incidence of gender bias. For example, if we rank India's 593 districts by the sex ratio of children aged 0-6 in the 2001 census, our sample includes the $3^{\text {rd }}$ (Kurukshetra, with a ratio of 770 girls per 100 boys), $10^{\text {th }}$ (Srangur, 784) and $22^{\text {nd }}$ (Karnal, 808) worst districts.

For the treatment villages, between December 2003 and February 2004, a randomly assigned recruiter would visit and make a small introduction at schools and to local leaders, announcing that they would be visiting the village at a designated date a few weeks later to provide information on employment opportunities in the BPO sector. They also contacted and worked with local leaders, government officials and NGOs to advertise the sessions.

Within a few weeks, the recruiters would visit the village and set up an information and recruiting session. The sessions were open to women only. ${ }^{11}$ All women could attend, but it was made clear that the job opportunities were primarily for women with a secondary school degree, and preferably some English language ability and experience with computers. This in effect ruled out a vast majority of women over the age of 25 ; for example, in our data only 8 percent of women aged 26-50 have completed secondary school.

The sessions were held in a range of facilities including schools and NGO or government offices, and typically lasted from 4 to 6 hours. The sessions drew a great deal of local interest and attendance was generally high. The recruiters did not have a fixed script, but were required to follow a specific organization. In particular, after introducing themselves, the recruiters provided: an overview of the BPO sector and the specific types of jobs and level of compensation available; information on the names of specific firms currently or frequently looking for workers; strategies for how to apply for jobs (how to create and submit resumes, plus lists of websites and phone numbers); interview skills lessons and tips; mock interviews;

\footnotetext{
${ }^{11}$ In a second set of 80 treatment villages, we provided recruiting services for both men and women. This treatment was designed to test both whether a "gender neutral" increase in economic opportunities would still benefit girls, as well as a theory of parental investment in children in the face of imperfect commitment. The latter requires a greater theoretical and empirical treatment of the parental decision making process, and is left to a companion paper (Jensen and Miller 2010). Here we simply note that the human capital gains for girls in this second set of treatment villages is very similar to what is found here.
} 
assessment of English language skills; and a question and answer session. The recruiters were required to emphasize that the jobs were competitive, so they were not in any way guaranteeing employment.

One and two years after the initial treatment (i.e., December 2004 to February 2005 and December 2005 to January 2006), we provided "booster shots," with the recruiters again visiting the same treatment villages and providing the same session. After each of the three sessions, the recruiters left their personal contact information so that any woman could follow up for additional information or assistance, at no cost. The recruiters were contracted to provide ongoing support for anyone from the designated villages. Thus, the intervention consisted (exclusively) of three in-depth sessions and three years of continuous placement support.

We wish to note that our goal is not to test whether recruiting services as a policy instrument can help address gender disparities in human capital. While it is certainly worthwhile to make sure that information on economic opportunities is widely available, our intervention does not actually create any new jobs for women. The women in our study may simply get jobs at the expense of other women, with no net effect on women's employment overall. ${ }^{12}$ The goal of the experiment is to supply exogenous variation in employment opportunities to test whether the change in potential returns influences household investment in girls.

One important aspect of the intervention worth highlighting is that the employment opportunities were white collar. While the distinction is commonly overlooked in the literature, for women the distinction may be particularly important. Boserup (1970), Costa (2000), Goldin (1990, 1995, 2006) and Mammen and Paxson (2000) argue that there may be less of a social stigma associated with women working in white collar jobs. These jobs are considered safer and "cleaner" than manual labor such as factory work. ${ }^{13}$ This may have particular relevance for India,

\footnotetext{
${ }^{12}$ Though if growth of the sector and competition with other BPO firms internationally was constrained by a shortage of skilled labor, or if providing information to a broader pool of potential applicants improves the quality of the worker-job match or increases overall productivity in the sector, net employment could potentially increase.

${ }_{13}$ Though there are some respects in which BPO jobs are considered less appropriate for women, particularly in rural areas. For example, women may have to commute for these jobs, and parents or husbands might perceive risks in women traveling alone. For more remote areas, taking one of these jobs might require migrating to a city and possibly living on their own, which parents may not want. Finally, some BPO jobs, particularly those in call centers servicing daytime hours in the United States, require working and commuting and night, which might be perceived as even less safe for women. Thus, some households would not want any female members to hold one of these jobs, and we expect they would therefore not be affected by the treatment (either in terms of employment or human capital).
} 
since an important aspect of the caste system is the designation that certain jobs, which are supposed to be set aside for "untouchables" outside the caste system, are considered "impure" or "polluting." Another relevant distinction is that women have a comparative advantage in this type of employment, since it does not require physical strength. We would therefore not necessarily generalize our findings to increases in the returns in agriculture (as in Foster and Rosenzweig 2009) or the blue-collar sector such as manufacturing (as in Atkin 2009). However, we feel the experiment is relevant for understanding the consequences of changes in women's employment for several reasons. First, the Indian economy, along with that of most other countries, is shifting towards the service sector, where white collar employment predominates. Services are the most rapidly growing sector in India, currently accounting for over $60 \%$ of GDP (up from $26-28 \%$ in the 1980s), with the IT sector alone comprising $8 \%$ of GDP (up from $1 \%$ just a decade ago). Second, throughout the world, much of the modern history of women's increasing paid labor force participation (particularly for married women) is driven by the white collar, service or clerical sectors (Boserup 1970, Goldin 1990, 1995, 2006, Costa 2000, Mammen and Paxson 2000). It was only in these sectors that jobs were considered to be acceptable or respectable for women. In fact, our experiment relating to information technology may be particularly apt in light of the historical evidence; for example, Goldin (2006) notes that the rise in female labor force participation in the United States in the early 20th century was due to growth in office and clerical jobs arising in part from innovations in information technology.

\section{DATA AND EMPIRICAL STRATEGY}

\section{A. Survey Information}

We conducted a baseline household survey during September and October of 2003 for each of the 160 treatment and control villages. The survey was conducted by students at the Management Development Institute, a business school outside of Delhi. In each of the villages, we worked with a local official to draw up a list of households, and randomly selected 20 households per village. The sampling was conducted independently of the intervention, and thus the sample contains some individuals that attended the recruiting sessions and some that did not.

The survey consisted of a household questionnaire and an adult questionnaire. The household questionnaire included questions on demographic and socioeconomic characteristics (age, sex, and education of all members, expenditures, etc.). We also asked for demographic and 
socioeconomic characteristics of all household members or children of members who have either temporarily or permanently left the household. The adult questionnaire was asked of all individuals aged 18 and older. This questionnaire included information on norms and expectations (work, marriage, dowry, old age support, etc.), the most relevant of which are described below.

Enumerators also weighed and measured the height of all household members aged 5 and older. ${ }^{14}$ If someone was not home at the time of the survey, enumerators scheduled up to three return visits to take these measurements, and would also visit other locations if the person lived away from home. As a result, we were able to get weight and height measurements for $98 \%$ of youths aged 5-15 (who will be the focus of our analysis) in round 1 and $99 \%$ in round 2. These data are particularly valuable because they are objective and thus more likely to accurately reflect changes in nutrition and health care provided to children.

A second round, follow-up survey with the same households was conducted in September and October of 2006. With a few exceptions noted below, the survey instrument for the second round was the same as the first, and enumerators again weighed and measured all household members aged 5 and older. We also tracked, and where possible measured, all individuals who left home between the rounds (such as for work or marriage).

Thus, overall, the project time-line was as follows. The baseline survey was conducted in August and September of 2003. The first recruiting sessions were carried out from December 2003 to February 2004. The follow-up, booster-shot recruiting sessions were carried out from December 2004 to February 2005 and December 2005 to February 2006. The second round survey was conducted in September and October of 2006. Recruiting assistance was available continuously from the time of the first session through the second round survey (and one year beyond that as well), spanning nearly 3 years.

Before turning to the data, we discuss attrition. Our analysis will focus on children aged 5-15 (in round 2), since most of these children will still live at home and therefore be measured. It is therefore important to examine attrition (or non-measurement in general) for this group, and

\footnotetext{
${ }^{14}$ Enumerators used consumer-grade bathroom scales and marked boards or measuring tape, and were trained to approximate as closely as possible the protocols in the 1988 National Health and Nutrition Examination Survey (NHANES) III manual. While the absence of a fixed setting and trained professionals likely introduced imprecision, the errors should be uncorrelated with the treatment and therefore should not bias our regression results.
} 
whether it is correlated with the treatment. One specific concern is the possibility that the intervention affected whether children left home due to work, school, marriage or death (all of which we gathered data on). ${ }^{15}$ As noted, we gathered information about children of household members who had left home, and where possible tracked and weighed and measured them. ${ }^{16}$ In our sample, the overall fraction of 5-15 year olds living away from home at baseline is less than 1 percent. Additionally, slightly less than 1 percent of children living at home could not be measured (for reasons including infirmity or temporary absence from the home). Total attrition for children aged 2-12 at baseline (and thus 5-15 at round 2) was 4.6 percent, about 3 percent of which was attrition of entire households (i.e., no one from the round 1 household was present at the same residence in round 2). ${ }^{17}$ Total attrition among girls 5-12 in the treatment villages was 4.7 percent, compared to 4.5 percent for the control villages. Though the difference in attrition for the treatment and control groups is small, it is possible there were large but offsetting effects of the treatment on attrition, and it is difficult to determine the possible bias this may introduce. Below, we assess the sensitivity of our results to assumptions on the outcomes of attriters.

\section{B. Descriptive Statistics}

Table I reports summary statistics for the full sample and separately by treatment status, as well as tests of treatment-control balance in baseline characteristics. The variables overall appear balanced between the control and the treatment groups. Formal tests suggest that randomization was successful: the $p$-value for the $F$-test that baseline characteristics jointly predict treatment is 0.71 and variable-by-variable individual tests cannot reject that the means are the same for treatment and control groups for almost all variables (column 4).

The table provides evidence of gender differences in education. The average adult woman's years of schooling is 1.8, compared to 3.8 for men. Similarly, only $74 \%$ of girls aged 7-

\footnotetext{
${ }^{15}$ The expected bias is difficult to predict. If the intervention lead to delayed marriage for girls with the greatest pre-treatment human capital (since they would benefit the most from staying in school longer to get a BPO job), the sample of non-attriting treatment girls will have greater human capital on average than the non-attriting control girls even if the treatment had no effect (though marriage is very uncommon for girls under age 15). Alternatively, the higher human capital children might be sent away to better schools because of the new economic opportunities, leaving the non-attriting treatment children with lower human capital on average than the non-attriting control children, again just due to selection.

${ }^{16} \mathrm{We}$ were able to locate and weigh and measure $62 \%$ of children $5-15$ who left home between rounds.

${ }^{17}$ For attriting households, we chose replacement households at random from the original population lists. Below we will use only the data from the panel, but the results are robust to including the replacements.
} 
15 are currently enrolled in school, compared to $87 \%$ of boys (all enrollment data were verified by contacting schools that students said they attended).

Since weight and height vary considerably over the 5-15 age range, we computed zscores for height-for-age (HFA) and Body Mass Index(BMI)-for-age (BFA) using the age- and sex-specific standards for school-aged children and adolescents developed by the World Health Organization (de Onis et al. 2007). These measures are considered the appropriate indicators of growth and development for children aged 5-19 and reflect the provision of nutrition and health care. ${ }^{18}$ The table shows that children in the sample are undernourished, with very low weight (BMI) and height relative to international norms. On average, children aged 5-15 are 1.2 to 1.3 standard deviations below their age- and sex-specific reference median BMI, and 2 standard deviations below the reference median height. The BMI and height data taken on their own do not however indicate any differential between boys and girls. This somewhat surprising result is also found in other data sets; for example, in the 3 rounds of the National Family Health Survey, there is almost no difference in anthropometric measures for boys and girls under the age of 5 (IIPS 1995, IIPS and ORC Macro 2000, IIPS and Macro International 2007), ${ }^{19}$ despite the fact that mortality rates for girls are significantly higher in this age range and a large literature documents differential treatment of boys and girls. There are several reasons why anthropometric measures may not detect gender differences, and it is beyond the scope of the present paper to resolve this issue. ${ }^{20}$ However, for our analysis, we will examine changes in BFA and HFA, which should reflect changes in the provision of nutrition and/or medical care.

The table also provides evidence about norms affecting investment in girls. In particular, adults aged 18 and older were asked whether they thought it was acceptable for women to work for pay away from home at various stages in their lives: before they are married; after they are married but before they have children; after they have children, but before those children have gone to school; after all their children are in school; and after their children have left the household. Overall, most people do not support women working for pay away from home. Only

\footnotetext{
${ }^{18}$ The WHO also computes weight-for-age standards, but only up to age 10 because it is not considered an informative measure for older children (de Onis et al. 2007), so we do not use it here.

${ }^{19}$ For example, in the 2005/6 survey measuring children 5 and under, the mean height-for-age, weightfor-height and weight-for-age z-scores are identical for boys and girls (-1.9, -1.0 and -1.8, respectively).

${ }^{20}$ For example, while lower nutrition should lead to girls being lighter and shorter for a given age, this may be offset by lower nutrition also causing death for the least healthy children. Deaton (2007) discusses the potential offsetting impacts of these "scarring" vs. "selection" effects.
} 
17 percent of adults believe it is appropriate for a woman to work for pay before marriage. This declines to 7 percent after she is married but before she has children. Not shown in the table, this declines even further to 4 percent when her children are not yet in school and 5 percent after all children are in school, then increases to 14 percent after all children have left the household.

Adults were also asked whether they think it is appropriate for adults to accept financial support from their sons and daughters in old age. The differences are striking. While almost all adults (97 percent) say it is appropriate to accept support from sons, only 4 percent say it is appropriate to accept support from daughters.

Thus, under prevailing norms/expectations, the incentive to educate girls may be quite low, especially compared to boys. While parents may still invest in their daughters for nonfinancial reasons, these investments may not respond to increases in market returns. Of course, these are just subjective, self-reports, which may deviate from true beliefs or practice in either direction. We view these data as simply suggestive, and consistent with the large anthropological and ethnographic literature.

\section{Empirical Strategy}

For each human capital measure, we present three specifications. First, we regress round 2 outcomes for children (aged 5-15 for weight-for-age and BMI-for-age, and 7-15 for schooling, since most children do not enroll until age 6 or 7) on an indicator for residing in a treatment village, separately for boys and girls: $Y_{i}=\beta_{0}+\beta_{1}$ Treatment $_{i}+\varepsilon_{i}$, where Treatment is a dummy equal to one if the child, $i$, lives in a village that was exposed to the recruiting intervention. We limit the sample to children under 15 to minimize selective attrition, given the increasing likelihood of leaving the household for work or marriage after this age. Limiting the sample in this way also means that we are examining changes in human capital (e.g., BMI) not for those individuals who got placed in one of the BPO jobs, but younger children for whom the recruiting sessions represent future economic opportunities, which their parents might respond to now.

The second specification adds controls that are baseline predictors of human capital, $Y_{i}=\beta_{0}+\beta_{1}$ Treatment $_{i}+\sum \gamma_{i} Z_{i}+\varepsilon_{i}$ (parent's education, $\log$ of family expenditure per capita, family size and child age). Our third specification uses the change in outcomes between rounds 1 and 2, rather than round 2 levels, $\Delta Y_{i}=\beta_{0}+\beta_{1}$ Treatment $_{i}+\varepsilon_{i}$, for children aged 5-12 in round 1 (and thus 8-15 in round 2). While the three specifications should yield similar estimates of the 
effect of the treatment, they will in general not be identical. For example, the samples they cover will be slightly different, since the changes specification cannot include children 5-7 in round 2 (because they will have been 2-4 in round 1, and thus not weighed or measured) or any children not measured in round 1 for reasons such as absence from the household. Further, although randomization should result in treatment and control groups being similar across all variables, in any particular sample there can be small baseline differences, and the regressions with controls or using changes will capture some of these differences.

For all specifications, we estimate linear regressions regardless of whether the outcomes are continuous or discrete, but limited dependent variable models yield nearly identical results. Standard errors are adjusted for clustering at the village level.

Since we are considering the impact of the treatment on a number of outcomes, in addition to presenting the results for each individual outcome, we present two other statistics. The first is the mean effect of the treatment across outcomes, computed using the methodology described in Kling, Liebman, and Katz (2007). This approach standardizes all variables to mean zero and unit standard deviation and redefines them where necessary so that a higher value constitutes an improvement. The average effect is computed as the unweighted average of the coefficient on the treatment variable for each of the standardized outcomes. We also provide $F$ tests of the null hypothesis that the effect of the treatment is jointly zero for all outcomes.

\section{RESULTS}

\section{A. Employment}

The recruiters reported placing a significant number of women in jobs in the treatment villages (about 900 over the three year period). Of course, some of these women might have gotten jobs in this sector or other sectors even without the recruiters, which we can net out through comparison to the control group. To assess the impact of the treatment on women's employment with our survey data, we regress an indicator for whether an individual works for pay in a non-family enterprise ${ }^{21}$ in the second survey round on an indicator for living in a

\footnotetext{
${ }^{21}$ We prefer this measure over BPO-only employment for several reasons. First, though we gathered detailed job data (via open-ended responses on occupation, industry and employer), defining the exact boundaries of the sector is difficult (just matching which women in our sample got a job from one of our recruiters would not capture the employment gain since some control and treatment women could have gotten these jobs without recruiters). Further, to the extent that the recruiters provided job search skills that helped women get jobs in other sectors (ex., bank teller), we would want to count these gains as well.
} 
treatment village. As noted above, employment data were gathered for all household members and children of members, including those not living at home (either temporarily or permanently), so we include these individuals in the sample as well. Since the treatment was focused only on younger women, we split the sample into age and sex categories.

Table II shows the results. In villages that received the recruiting treatment, paid employment was 2.4 percentage points higher for women aged 18-24. The effect is large when compared to the Round 2 control group mean for women of this age of about 21 percent. ${ }^{22}$ As expected given the experimental design, there was no change in paid employment for women aged 25-44 or 45 and older. The coefficients for these two groups are extremely small and not statistically significant. Similarly, there is no impact on employment for men of any age, again consistent with the experimental design. Thus overall, the recruiting intervention increased employment specifically for the set of younger women it was targeted towards, and only those women. ${ }^{23}$ It is these gains that we predict may have effects on investments in girls.

\section{B. Effect on Human Capital}

Table III shows the effects of the treatment on education and anthropometric measures. The first set of columns shows the specification where the dependent variable is Round 2 outcomes with no additional controls, the middle columns add baseline controls, and the last columns examine changes in outcomes between the two rounds. Girls (top panel) were about 5 percentage points more likely to be enrolled in school in the treatment villages. The coefficient is robust across the three specifications, and statistically significant at the 1 percent level in all

Finally, if we focus only on BPO jobs, we could overestimate the impact of the treatment since some women may just shift to this sector from, say, other white collar jobs, with no net gain in employment.

${ }^{22}$ It is unlikely that the jobs gained in treatment villages came at the expense of women in the control villages. The pool of women competing for these jobs is large, so the loss of jobs within our set of control villages is likely to be very small; and since few women in rural areas get these jobs, any losses are likely to be found in urban areas, which are outside our sample. Though the interpretation would largely be the same in the face of such effects; observing human capital reductions for girls where job opportunities for women decline would still show that returns affect investments (unless we believe there are asymmetric effects where girls are harmed when opportunities decline but do not gain when they increase).

${ }^{23}$ The intervention could have lead to employment gains for men or older women if those who attended the sessions shared the information or helped recruit others once they got a job. However, most older women are married and do not work, have too little education or do not speak English. There are several reasons why men's employment may not have changed: men may have already had access to other higheducation jobs; BPO employers may also have preferred to hire women; and caste-based job networks may have limited men's occupational mobility, as found in Munshi and Rosenzweig (2006). 
cases. The effects are large, representing about 6-7 percent gains for the treatment group relative to the control group (control group means are presented at the bottom of each column), and close about 40 percent of the baseline boy-girl gap in enrollment (Table I).

Columns 2, 5 and 8 show that the treatment also resulted in an average increase in BMIfor-age z-score of about $0.20-0.30$ for girls, again significant at the 1 percent level in all specifications. The effect is fairly large, particularly relative to the control group mean deficit of 1.3; the treatment closed about 15-20 percent of the BMI gap between our sample and the wellnourished WHO reference population. Finally, columns 3,6 and 9 show that point estimates of the effect of the treatment on height-for-age are positive, but very small and not statistically significant in any of the specifications. ${ }^{24}$

Overall, we find positive point effects of the treatment on human capital outcomes for all three measures, but only two of the three are statistically significant. The bottom rows of the panel provide a summary assessment of the effects. With both the Kling-Liebman-Katz average effect and the $F$-test, we can reject the hypothesis that the treatment had no effect across the set of human capital measures for girls at the one percent level or better for each of the three empirical specifications.

The bottom panel of the table shows the effect of the treatment for boys. The coefficients are small across all three human capital measures in all specifications, and none are statistically significant. The absence of an effect for boys is consistent with the intervention having increased the expected returns for girls only. However, it is perhaps surprising that parents were able to increase investments in girls without decreasing investment in boys. This suggests that poverty and credit constraints may not be as important as "demand constraints" in limiting investment in girls, i.e., parents may be providing little to girls not because they can't afford to, but because they don't find it optimal to, due to low expected returns.

Of course, we are only able to measure short-run effects, and the longer run effects may be greater or smaller. For example, if a girl is provided better nutrition or health care for more than three years, there may be a greater cumulative effect on weight or height. Also, our anthropometric results focus on children aged 5 to 15, and the effects of nutrition or health care may be greater for infants (Russell and Rhoads 2008). Alternatively, it is possible we overstate

\footnotetext{
${ }^{24}$ The medical literature suggests that nutrition appears to have little effect on height after the age of 2 , including any possible "catch up" effects (Russell and Rhoads 2008). Thus, though we were not aware of it when designing the study, it is perhaps not surprising that we find no effect of the treatment on height.
} 
the long-run effects; improved nutrition for younger girls may simply lead to an earlier onset of puberty, rather than long-term gains in weight. ${ }^{25}$ The effect of nutrition and medical care on the onset of puberty and long-term outcomes is complex, and beyond the scope of the present paper to determine. However, for our conclusions, even if the intervention only lead to an earlier onset of puberty with no ultimate adult weight gain, this would still serve as an indicator that there had been greater nutrition and/or health care investments in girls. Our interest in the anthropometric measures is as an indicator of those unobserved investments; it seems unlikely there is another mechanism through which the intervention might have influenced the onset of puberty, so we would still conclude that nutrition and/or health care for girls had improved in response to the increased potential returns. Finally, we should also mention that it is possible that the long-run effects of our intervention may be smaller than what is observed here if parents "overreact" to the treatment and overestimate the future returns to girls' human capital, and later adjust expectations downward (because, say, they observe that not every woman gets a high paying BPO job). However, again, our goal is not to test the impact of this recruiting intervention as a policy instrument, but whether some signal of increased returns leads to greater investment in girls.

\section{Attrition}

As noted, because we are only able to weigh and measure children living at home, we may be selectively missing some girls who differ in human capital from those still living at home. Though at baseline there should be no difference between treatment and control villages along this dimension, if our intervention caused some girls to stay home longer, such as by delaying marriage for work or more schooling, we may systematically skew the treatment sample and conclude there is an effect of the treatment even if there is none (we noted above that the treatment and control groups have similar attrition rates, but there could be offsetting effects). Attrition has less of an impact for our schooling measure, since parents are asked to provide information on schooling for children not at home (which we verify by contacting schools); thus, we primarily lose data for children whose entire household has attrited.

Rather than modeling attrition, Table IV shows that our results continue to hold even under a fairly extreme assumption about the outcomes of children not living at home in Round 2. In particular, we assign all non-measured treatment children as not being in school, and give

\footnotetext{
${ }^{25}$ Though in this case we would expect to see differences in height.
} 
them a BMI and height (or changes in BMI and height) equal to the 25th percentile of the corresponding distribution for other children of their age and sex, while all non-measured control children are assigned as being in school and given the 75th percentile of their age*sex BMI and height distributions. Though we have no reason to believe children from the treatment group that are not measured are any worse off than children from the control group that are not measured, even under this assumption that works strongly against our finding an effect, the coefficient for the treatment indicator is still statistically significant for girls at the 10 percent level or better for schooling and BFA. Using the Kling-Liebman-Katz and $F$-tests, we still reject at the 5 percent level or better that the treatment had no effect on human capital outcomes. ${ }^{26}$

\section{Distinguishing Returns From Other Mechanisms}

While the increase in human capital for girls is consistent with parents responding to the increased awareness of the returns to human capital for women, as noted above there are many alternative reasons why economic opportunities for women might lead to greater investments in girls. Of course, even in these cases, the intervention would still show that increases in women's employment opportunities have a causal effect on girls' human capital, which is a valuable result in itself. However, it is important to understand the mechanism underlying this relationship, which other studies have not been able to identify. Our goal is not to reject that these other mechanisms are ever relevant, but simply to demonstrate that in our case they are not operative, and thus show that changes in returns can have a direct effect on girls' human capital. As noted, the key factor is that most of the non-returns mechanisms (bargaining power, change in the household allocation of time, etc.) result from changes in the mother's employment, whereas the returns mechanism is based solely on the potential future economic opportunities of currently young girls (and thus would take place even with no change in mother's employment).

First, the results are unlikely to be explained by increases in mother's bargaining power when she gets a job, the most commonly proposed alternative mechanism. The intervention was chosen to target the employment opportunities of younger women almost exclusively, in that older women are less likely to have finished high school, speak English or have computer experience. The recruiters also told us that most BPO firms prefer to hire young, unmarried women, which is confirmed by Oster and Millet (2010) and Ng and Mitter (2005). More

\footnotetext{
${ }^{26}$ For boys, some of the negative effects are statistically significant under these assumptions.
} 
generally, in our rural sample very few women with young children work for pay (less than 5 percent). This is likely to be even more binding for our intervention, since the BPO jobs are not rural based, but require commuting or migration. Turning to the data, Table II shows there was no increase in paid employment for women over age 25, and few women 24 or younger are likely to have children aged 5 or older. In addition, for women with children 5-15, if we regress Round 2 paid employment on an indicator for the treatment, we get a coefficient of 0.00321 with a standard error of 0.029 . Thus, there were no employment gains for mothers of the children whose human capital we analyzed. Finally, we can also rule out that the gains for girls are due to the increased bargaining power of newly working mothers (or other adult women in the household) by considering households that do not have any women (either living at home or temporarily or permanently away from home) who work for pay in Round 2. The top panel of Table V shows that the effects continue to hold for this sample. ${ }^{27}$

Of course, it is possible that the mother's bargaining power may increase even if she does not work, simply by the possibility or threat that she could. However, this seems less likely to apply in the present case. As noted, most of the jobs that we increased access to require a secondary school degree, which few older women have. And while a full test of this hypothesis isn't possible, we can examine whether the treatment had an effect for households with women for whom the threat of getting a BPO job was much lower, i.e., they do not have a high school degree. $^{28,29}$ In the middle panel of Table V, we see that the effects are very similar in magnitude to the results for the full sample of women in Table III, and remain statistically significant at the 1 percent level. Finally, we can also examine some simple measures of women's bargaining power. The survey asked women whether they participated in household decision-making for a range of activities (children's schooling and health care; obtaining health care for themselves; purchasing major household items; and visiting friends or family) as well as their "autonomy" (whether they can visit the market without permission; visit family or friends without

\footnotetext{
${ }^{27}$ One potential problem with this test is that we stratify on a choice variable affected by our intervention. We could instead look at subsamples where not having a woman work is a function of factors exogenous to the treatment. For example, it is unlikely there will be a woman working as a result of the intervention in households where no adult female member has a high school education. This test is presented next.

${ }^{28}$ Of course, there are many employment opportunities for women without a high school degree. However, our treatment is unlikely to have caused a change in access to those opportunities.

${ }^{29}$ While this is a select sample (though still a vast majority of women), we might perhaps otherwise expect the treatment to have a smaller effect for this group, since their lower education may signal that they have lower preferences for education, perhaps even specifically with regards to girls.
} 
permission; and whether they were permitted to keep money set aside to spend as they wish). Creating two indexes as the sum of the responses to these questions, we find that the treatment does not have a statistically significant impact on women's autonomy or participation in decision-making. ${ }^{30}$ While these are only self-reports and thus may have reporting errors, provided those errors are uncorrelated with the treatment, the results are at least consistent with the conclusion that women's bargaining power did not change as a result of the treatment.

A final possibility to consider is that a mother's bargaining power may be increased even if she doesn't work and has no increased possibility of working, if an older daughter works and sends money to her mother. The holding of cash alone may increase the mother's bargaining power and thereby improve investments in her other daughters. ${ }^{31}$ To rule this out, we can examine households where no child is older than 16, and thus could not have gotten one of the BPO jobs. ${ }^{32}$ The results in the bottom panel of Table V show the gains for girls continue to hold for this sample.

Thus, overall we conclude that a change in the mother's bargaining power is unlikely to explain our effects. Similar arguments (i.e., that the BPO opportunities are current or future opportunities for daughters, not women old enough to already be mothers themselves, and that the effects hold even in households where no women work), can rule out several other mechanisms: that parents invest more in girls because they become more valuable to the household when the mother works; changes in the couple's intended fertility, via changes in the value of the mother's time; or that a working mother means others take over care of her children, and may provide more equal treatment than she does. The fact that we find an effect of the treatment even in households where no women work also rules out that the gains are driven by female household members other than the mother getting one of the jobs (e.g., if an older daughter got a job, she might send money to her younger sisters to buy food or health care to

\footnotetext{
${ }^{30}$ The coefficient on the treatment indicator is $0.112(0.347)$ when autonomy is the dependent variable (control group mean 1.38) and -0.071 (0.184) when it is participation in decision-making (mean 1.64).

${ }^{31}$ Alternatively, the mother may just directly use the money to increase spending on her daughters, either by not telling her husband (so he doesn't offset the additional expenditures) or if the money is more than what was previously being spent on children.

${ }^{32}$ The previous results where no women work (including those away) also eliminates this possibility.
} 
compensate for poor treatment by their parents, or her younger sisters might now be more valuable to the household because they take over the older sister's household responsibilities). ${ }^{33}$

Finally, we can explore whether our experiment affected human capital investments in girls via changes in income. Changes in current income can be ruled out as in Table V, where there were gains for girls even in households where no woman (including those who have temporarily or permanently left home) works for pay. ${ }^{34}$ Regarding changes in future or permanent/lifetime income (e.g., since a daughter or the mother may work in the future), Table III showed that the intervention had no effect for boys. If the gains for girls are driven by increases in parents' expected lifetime wealth, we would expect at least some human capital gains for boys as well (in fact, we often expect greater effects of wealth on boys than girls; Table II provides some evidence of that in the present case). While girls' education may be considered a luxury, so we might expect greater increases for girls than boys in response to wealth increases once the household is beyond a certain threshold, given the diversity of wealth in our sample it seems unlikely that all households just happened to be at the exact wealth level where boys were receiving what the household considered to be the optimal amount of schooling and health, so that all marginal increases in wealth go only to girls' human capital, with no effect at all for boys (especially since boys are still very malnourished by international standards, as seen in Table I).

Thus, overall, while there is no test that can rule out every alternative, most of the primary explanations put forward (changes in bargaining power, income, fertility or household time allocation) are not applicable in the present case because the opportunities were (per our intent and design) not for current mothers. It therefore seems likely that it was the increase in the potential future value of human capital that lead to increased investment in girls.

However, although we can rule out these alternative mechanisms, we do not wish to claim that the results are driven entirely by future monetary rewards to women's human capital. Parents may expect greater non-market returns for their daughters from these jobs, perhaps even

\footnotetext{
${ }^{33}$ Similar results hold if we look at younger couples (under 35) who could not yet have children old enough to get one of the BPO jobs or, as noted, households where no child is over 16. Stratifying in this way is less likely to be endogenous with respect to girl's outcomes than whether a woman works.

${ }^{34} \mathrm{We}$ also note that changes in current income could not explain all of the observed human capital gains, since the 5 percentage point increase in school enrollment is greater than the 2.4 percentage point increase in employment. It would then have to be that every woman who got a job had on average almost 2 girls aged 5-15, who additionally went from none enrolled to all enrolled, which seems very unlikely.
} 
including greater bargaining power in their future marital household. ${ }^{35}$ However, the experiment still represents the appropriate one, since these non-monetary gains will also be associated with much of the gains in women's employment being realized today in India, and observed in the past in wealthy countries. What is most relevant is that we can still identify parents as having made forward-looking decisions regarding their daughters based on some perceived increased future value of their human capital, i.e., that investment in girls will respond to increases in their future economic opportunities. This remains distinct from changes in investments in young girls driven by changes related to the mother's employment, such as her greater ability to influence household expenditure or allocation decisions regarding children. Even just ruling out for the present case the other mechanisms operating via mother's employment is informative because if the lesson of the large literature linking women's employment and investment in girls is that it is all driven by bargaining power, fertility, etc., there may be other policy instruments available (e.g., reform or enforcement of divorce laws, strengthening women's inheritance or property rights, family planning services, etc.) that also address these factors, and that may perhaps be more direct or effective. Another way to view this is that our results show that it is possible to have gains for girls without first needing to change bargaining power, income or fertility.

\section{DISCUSSION AND CONCLUSION}

We find that an intervention making employment opportunities for women more salient and accessible increased human capital investments in girls. Two key advantages of this study are that we supply exogenous variation in opportunities for women and that we can exclude other explanations for the link between employment opportunities and investment in girls, such as mother's bargaining power or the allocation of time within the household.

Our intervention did not create any new jobs for women, and thus we do not view recruiting as a solution to the problem of gender disparities in human capital. Rather, the value of our results is in demonstrating that human capital investments in girls respond to their future economic opportunities. Many approaches to gender bias by governments, NGO's, rights groups and international organizations have emphasized the social or cultural component of bias (Croll

\footnotetext{
${ }^{35}$ Thus, we do not wish to argue that bargaining power is irrelevant to girls' human capital attainment, but instead to emphasize the distinction between bargaining power wielded by the mother and best viewed as acting on the current household decision-making process, vs. bargaining power that is just one of many future benefits the child herself may receive from human capital investment and future employment.
} 
2001). While there is certainly some role for such efforts, our results suggest that expanding economic opportunities for women, which should involve a focus on the private sector, can play an important role in reducing gender disparities in human capital. Public policy instruments include enforcement of anti-discrimination laws in hiring and promotion, and ensuring equality in public sector employment and promotions. Other instruments include reducing barriers to women entering the labor market, such as workplace laws strengthening part-time work and maternity leave or expanding women's access to credit, either via commercial banks or microfinance programs, so women can engage in more entrepreneurial activities (though Field, Jayachandran and Pande 2010 discuss possible barriers to this kind of activity for women).

The results also suggest there are likely to be improvements in women's human capital even in the absence of policy interventions. The rise of the BPO sector, along with rapid growth in the white-collar service sector more generally, has been shifting the Indian economy away from agriculture and manufacturing. Though employment growth in these new sectors has been slower than the growth in their GDP share, this shift is likely to continue to generate a greater demand for female labor and a corresponding increase in female labor force participation, as has been observed in other countries (Goldin 1990, 1995, 2006). And historical evidence suggests such changes can be rapid. As recently as the 1960s, paid labor force participation rates were only around 30 percent in both the United States and Great Britain, increasing to 58 and 71 percent respectively in less than three decades (Costa 2000). Our results indicate that any coming gains in employment opportunities for women will likely result in human capital gains as well.

Finally, the results are also valuable in that they show that there is a demand side limitation to investment in girls for at least some households. For these households, the limiting factor in investment in girls is not related to poverty, or access, costs, distance or quality of schooling, nutrition or health care. Though these other factors are certainly important concerns, at least some of the problem of low human capital for girls is that parents see little value to investing in them. Our experiment shows that clear and salient evidence of greater returns can lead to gains for girls even without changes in any of these other factors.

\section{REFERENCES}

Agarwal, Bina (1994). A Field of One's Own: Gender and Land Rights in South Asia. Cambridge: Cambridge University Press.

Agnihotri, Satish, Richard Palmer-Jones, and Ashok Parikh (2002). "Missing Women in Indian Districts: A Quantitative Analysis." Structural Change and Economic Dynamics, 13, p. 285-314.

Atkin, David (2009). "Working for the Future: Female Factory Work and Child Health in Mexico," Yale University. 
Bardhan, Pranab K. (1974). “On Life and Death Questions,” Economic and Political Weekly, 9, p. 1293-1304.

Behrman, Jere R. (1997). "Intrahousehold Distribution and the Family," in Mark Rosenzweig and Oded Stark, eds., Handbook of Population and Family Economics. Amsterdam: Elsevier Science.

- -, - -, and - - (1988). "Intrahousehold Allocation of Nutrients in Rural India: Are Boys Favored? Do Parents Exhibit Inequality Aversion?" Oxford Economic Papers, 40 (1), p 32-54.

- - Andrew D. Foster, Mark R. Rosenzweig and Prem Vashishtha (1999). "Women's Schooling, Home Teaching, and Economic Growth," Journal of Political Economy, 107(4), p. 682-714.

Boserup, Esther (1970). Woman's Role in Economic Development. London: Allen and Unwin.

Chen, Lincoln C., Emdadul Huq, and Stan D'Souza (1981). "Sex Bias in the Family Allocation of Food and Health Care in Rural Bangladesh," Population and Development Review 7 (1), p. 55-70.

Chen, Martha Alter (2000). Perpetual Mourning: Widowhood in Rural India. Oxford University Press: New Delhi.

Costa, Dora (2000). "From Mill Town to Board Room: The Rise of Women's Paid Labor," Journal of Economic Perspectives, 14(4), p. 101-122.

Croll, Elizabeth (2000). Endangered Daughters: Discrimination and Development in Asia. Routledge: London.

de Onis, Mercedes, Adelheid W. Onyango, Elaine Borghi, Amani Siyam, Chizuru Nishida, and Jonathan Siekmann, J. (2007). "Development of a WHO Growth Reference for School-aged Children and Adolescents," Bulletin of the World Health Organization, 85, p. 661-668.

Das Gupta, Monica (1987). "Selective Discrimination against Female Children in Rural Punjab, India," Population and Development Review, 13(1), p. 77-100.

- -, Woojin Chung and Li Shuzhou (2009). "Evidence for an Incipient Decline in Numbers of Missing Girls in China and India," Population and Development Review, 35(2), p. 401-16.

Deaton, Angus (2007). "Height, Health and Development," Proceedings of the National Academy of Sciences, 104(33), p. 13232-13237.

Dube, Leela and Rajni Palriwala (1990). Structures and Strategies: Women, Work, and Family. New Delhi: Sage.

Duflo, Esther (2005). "Gender Equality in Development," Manuscript, Department of Economics, MIT.

Dyson, Tim, and Mick Moore (1983). "On Kinship Structure, Female Autonomy, and Demographic Behavior in India," Population and Development Review, 9(1), p. 35-60.

Field, Erica, Seema Jayachandran and Rohini Pande (2010). "Do Traditional Institutions Constrain Female Entrepreneurship? A Field Experiment on Business Training in India," American Economic Review.

Foster, Andrew and Mark R. Rosenzweig (2009). "Missing Women, the Marriage Market, and Economic Growth," Brown University Working Paper.

Goldin, Claudia (1990). Understanding the Gender Gap: An Economic History of American Women. New YorkOxford: Oxford University Press.

-- (1995). "The U-Shaped Female Labor Force Function in Economic Development and Economic History," in T. Paul Schultz, ed. Investment in Women's Human Capital. Chicago: University of Chicago Press.

- (2006). "The Quiet Revolution That Transformed Women's Employment, Education, and Family," American Economic Review, 96(2), p. 1-21.

Haddad, Lawrence, John Hoddinott and Harold Alderman (1997). Intra-household Resource Allocation in Developing Countries: Models, Methods, and Policy. Baltimore: Johns Hopkins University Press.

Holman, David, Rosemary Batt and Ursula Holtgrewe (2007). The Global Call Centre Report: International Perspectives on Management and Employment. Global Call Centre Research Network.

International Institute for Population Sciences (IIPS) and Macro International (1995). National Family Health Survey (MCH and Family Planning), India 1992-93. Mumbai: IIPS.

- - and ORC Macro (2000). National Family Health Survey (NFHS-2), 1998-99: India. Mumbai: IIPS.

- - and Macro International (2007). National Family Health Survey (NFHS-3), 2005-06: India. Mumbai: IIPS.

Jensen, Robert T. (2010). "The (Perceived) Returns to Education and the Demand for Schooling," Quarterly Journal of Economics, 25(2), p. 515-548.

- - and Nolan Miller (2010). "Keepin' 'em Down on the Farm: Old Age Security and Strategic Underinvestment in Boys," mimeo UCLA.

Kishor, Sunita (1993). "May God Give Sons to All': Gender and Child Mortality in India," American Sociological Review, 58, p. 247-265.

-- (1995). "Gender Differentials in Child Mortality in India: A Review of Evidence" in Women's Health in India, Monica Das Gupta, T. N. Krishnan and Lincoln Chen. Bombay: Oxford University Press.

Kling, Jeffrey R., Jeffrey B. Liebman and Lawrence F. Katz (2007). "Experimental Analysis of Neighborhood Effects," Econometrica, 75(1), p. 83-119. 
Mammen, Kristin and Christina Paxson (2000). "Women's Work and Economic Development," Journal of Economic Perspectives, 14(4), p. 141-164.

Miller, Barbara D. (1981). The Endangered Sex: Neglect of Female Children in Rural North India. Ithaca, New York: Cornell University Press.

Munshi, Kaivan and Mark Rosenzweig (2006). "Traditional Institutions Meet the Modern World: Caste, Gender, and Schooling in a Globalizing Economy,” American Economic Review, 96(4), 1225-1252.

Murthi, Mamta, Anne-Catherine Guio and Jean Drèze (1995). "Mortality, Fertility and Gender Bias in India: A District-Level Analysis," Population and Development Review, 21(4), p. 745-782.

Ng, Cecilia and Swasti Mitter (2005). "Valuing Women's Voices: Call Center Workers in Malaysia and India," Gender, Technology and Development, 9(2), p. 209-233.

Oster, Emily and M. Bryce Millett (2010). "Do Call Centers Promote School Enrollment? Evidence from India," mimeo, University of Chicago.

Qian, Nancy (2008). "Missing Women and the Price of Tea in China: The Effect of Sex-Specific Earnings on Sex Imbalance," Quarterly Journal of Economics, 123(3), p. 1251-1285.

Rosenzweig, Mark and T. Paul Shultz (1982). "Market Opportunities, Genetic Endowments and Intrafamily Resource Distribution: Child Survival in India," American Economic Review, 72 (4), 803-815.

Russell, William E. and J. Marc Rhoads (2008). "Nutrition and the Humoral Regulation of Growth," in Christopher Duggan, John B. Watkins and W. Allan Walker, eds. Nutrition in Pediatrics. Ontario: BC Decker.

Schultz, T. Paul (1990). "Testing the Neoclassical Model of Family Labor Supply and Fertility," Journal of Human Resources, 25(4), p. 599-634.

- - (2001). "Women's Roles in the Agricultural Household: Bargaining and Human Capital Investments" in Agricultural and Resource Economics Handbook, B. Gardner and G. Rausser, Amsterdam: Elsevier Publishing.

Sen, Amartya (1990). "More than 100 Million Women are Missing," New York Review of Books, December 20.

- - and Sunil Sengupta (1983). "Malnutrition of Rural Children and the Sex Bias," Economic and Political Weekly, $18(19 / 21)$, p. 855-864.

Shastry, Gauri Kartini (2010). "Human Capital Response to Globalization: Education and Information Technology in India," mimeo, Wellesley College.

Strauss, John and Duncan Thomas (1995). "Human Resources: Empirical Modeling of Household and Family Decisions," in T.N. Srinivasan and Jere Behrman, eds., Handbook of Development Economics, Vol. 3A, Amsterdam: Elsevier Publishing, p. 1883-2023.

-- and -- (1998). "Health, Nutrition and Economic Development," Journal of Economic Literature, 36(2), p.766-817.

Thomas, Duncan (1990). "Intra-household Resource Allocation: An Inferential Approach," Journal of Human Resources, 25(4), p. 635-64.

Visaria, Pravin M. (1969). The Sex Ratio of the Population of India, Census of India 1961, Vol. 1, Monograph \#10. 


\begin{tabular}{|c|c|c|c|c|}
\hline & $\begin{array}{l}(1) \\
\text { All } \\
\end{array}$ & $\begin{array}{c}\text { (2) } \\
\text { Control } \\
\end{array}$ & $\begin{array}{c}\text { (3) } \\
\text { Treatment }\end{array}$ & $\begin{array}{c}(4) \\
\text { Difference } \\
(3)-(2) \\
\end{array}$ \\
\hline Log (expenditure per capita) & $\begin{array}{c}6.38 \\
{[0.66]}\end{array}$ & $\begin{array}{c}6.37 \\
{[0.65]}\end{array}$ & $\begin{array}{c}6.38 \\
{[0.67]}\end{array}$ & $\begin{array}{c}0.01 \\
(0.023)\end{array}$ \\
\hline Head's years of schooling & $\begin{array}{c}3.76 \\
{[3.77]}\end{array}$ & $\begin{array}{c}3.67 \\
{[3.72]}\end{array}$ & $\begin{array}{c}3.86 \\
{[3.81]}\end{array}$ & $\begin{array}{c}0.19 \\
(0.13)\end{array}$ \\
\hline Spouse's years of schooling & $\begin{array}{c}1.80 \\
{[2.67]}\end{array}$ & $\begin{array}{c}1.79 \\
{[2.62]}\end{array}$ & $\begin{array}{c}1.80 \\
{[2.72]}\end{array}$ & $\begin{array}{c}0.022 \\
(0.094)\end{array}$ \\
\hline Family Size & $\begin{array}{c}5.46 \\
{[2.37]}\end{array}$ & $\begin{array}{c}5.42 \\
{[2.41]}\end{array}$ & $\begin{array}{c}5.49 \\
{[2.32]}\end{array}$ & $\begin{array}{c}0.072 \\
(0.084)\end{array}$ \\
\hline Expect Money From Son When Old & $\begin{array}{c}0.96 \\
{[0.19]}\end{array}$ & $\begin{array}{c}0.97 \\
{[0.18]}\end{array}$ & $\begin{array}{c}0.96 \\
{[0.20]}\end{array}$ & $\begin{array}{l}-0.007 \\
(0.007)\end{array}$ \\
\hline Expect Money From Daughter When Old & $\begin{array}{c}0.04 \\
{[0.20]}\end{array}$ & $\begin{array}{c}0.04 \\
{[0.20]}\end{array}$ & $\begin{array}{c}0.04 \\
{[0.20]}\end{array}$ & $\begin{array}{c}0.003 \\
(0.007)\end{array}$ \\
\hline Appropriate for women to work for pay: & & & & \\
\hline Before marriage & $\begin{array}{c}0.16 \\
{[0.37]}\end{array}$ & $\begin{array}{c}0.16 \\
{[0.37]}\end{array}$ & $\begin{array}{c}0.16 \\
{[0.37]}\end{array}$ & $\begin{array}{c}-0.002 \\
(0.014)\end{array}$ \\
\hline After married, before children & $\begin{array}{c}0.068 \\
{[0.25]}\end{array}$ & $\begin{array}{c}0.066 \\
{[0.25]}\end{array}$ & $\begin{array}{c}0.071 \\
{[0.26]}\end{array}$ & $\begin{array}{c}0.006 \\
(0.009)\end{array}$ \\
\hline In school: girls 7-15 & $\begin{array}{c}0.74 \\
{[0.44]}\end{array}$ & $\begin{array}{c}0.75 \\
{[0.43]}\end{array}$ & $\begin{array}{c}0.74 \\
{[0.44]}\end{array}$ & $\begin{array}{c}-0.011 \\
(0.020)\end{array}$ \\
\hline In school: boys $7-15$ & $\begin{array}{c}0.87 \\
{[0.34]}\end{array}$ & $\begin{array}{c}0.87 \\
{[0.34]}\end{array}$ & $\begin{array}{c}0.86 \\
{[0.35]}\end{array}$ & $\begin{array}{c}-0.010 \\
(0.015)\end{array}$ \\
\hline BMI-for-age (z-score): girls 5-15 & $\begin{array}{l}-1.25 \\
{[1.35]}\end{array}$ & $\begin{array}{l}-1.25 \\
{[1.38]}\end{array}$ & $\begin{array}{l}-1.26 \\
{[1.33]}\end{array}$ & $\begin{array}{l}-0.015 \\
(0.057)\end{array}$ \\
\hline BMI-for-age (z-score): boys 5-15 & $\begin{array}{l}-1.31 \\
{[1.54]}\end{array}$ & $\begin{array}{c}-1.29 \\
{[1.51]}\end{array}$ & $\begin{array}{c}-1.34 \\
{[1.55]}\end{array}$ & $\begin{array}{c}-0.056 \\
(0.065)\end{array}$ \\
\hline Height-for-age (z-score): girls 5-15 & $\begin{array}{l}-2.03 \\
{[1.34]}\end{array}$ & $\begin{array}{l}-2.02 \\
{[1.32]}\end{array}$ & $\begin{array}{l}-2.04 \\
{[1.37]}\end{array}$ & $\begin{array}{l}-0.014 \\
(0.057)\end{array}$ \\
\hline Height-for-age (z-score): boys 5-15 & $\begin{array}{l}-2.01 \\
{[1.36]}\end{array}$ & $\begin{array}{c}-1.99 \\
{[1.36]}\end{array}$ & $\begin{array}{c}-2.03 \\
{[1.33]}\end{array}$ & $\begin{array}{c}-0.034 \\
(0.056)\end{array}$ \\
\hline
\end{tabular}


TABLE II. EFFECT OF THE INTERVENTION ON PAID EMPLOYMENT

\begin{tabular}{lcccccc}
\hline \hline & & & & & \\
& $(1)$ & $\frac{\text { WOMEN }}{(2)}$ & $(3)$ & $(4)$ & $\underline{(5)}$ & $(6)$ \\
& $18-24$ & $25-44$ & $45-60$ & $18-24$ & $25-44$ & $45-60$ \\
\cline { 2 - 7 } Treatment & $0.024^{* *}$ & 0.0031 & -0.006 & 0.002 & 0.006 & -0.004 \\
& $(0.010)$ & $(0.0088)$ & $(0.013)$ & $(0.011)$ & $(0.023)$ & $(0.033)$ \\
$\mathrm{R}^{2}$ & 0.054 & 0.001 & 0.000 & 0.000 & 0.001 & 0.000 \\
\hline
\end{tabular}

Notes: Heteroskedasticity-consistent standard errors accounting for clustering at the village-level in parentheses. All variables measured in round 2 survey. Dependent variable is an indicator for whether an individual was in paid employment in the round 2, post-treatment survey. All regressions also include an indicator for whether expenditure data was unavailable (these household are assigned the median sample expenditure). ${ }^{*}$ Significant at 10 percent level. **Significant at 5 percent level. ***Significant at 1 percent level. 
TABLE III. EFFECT OF THE INTERVENTION ON HUMAN CAPITAL

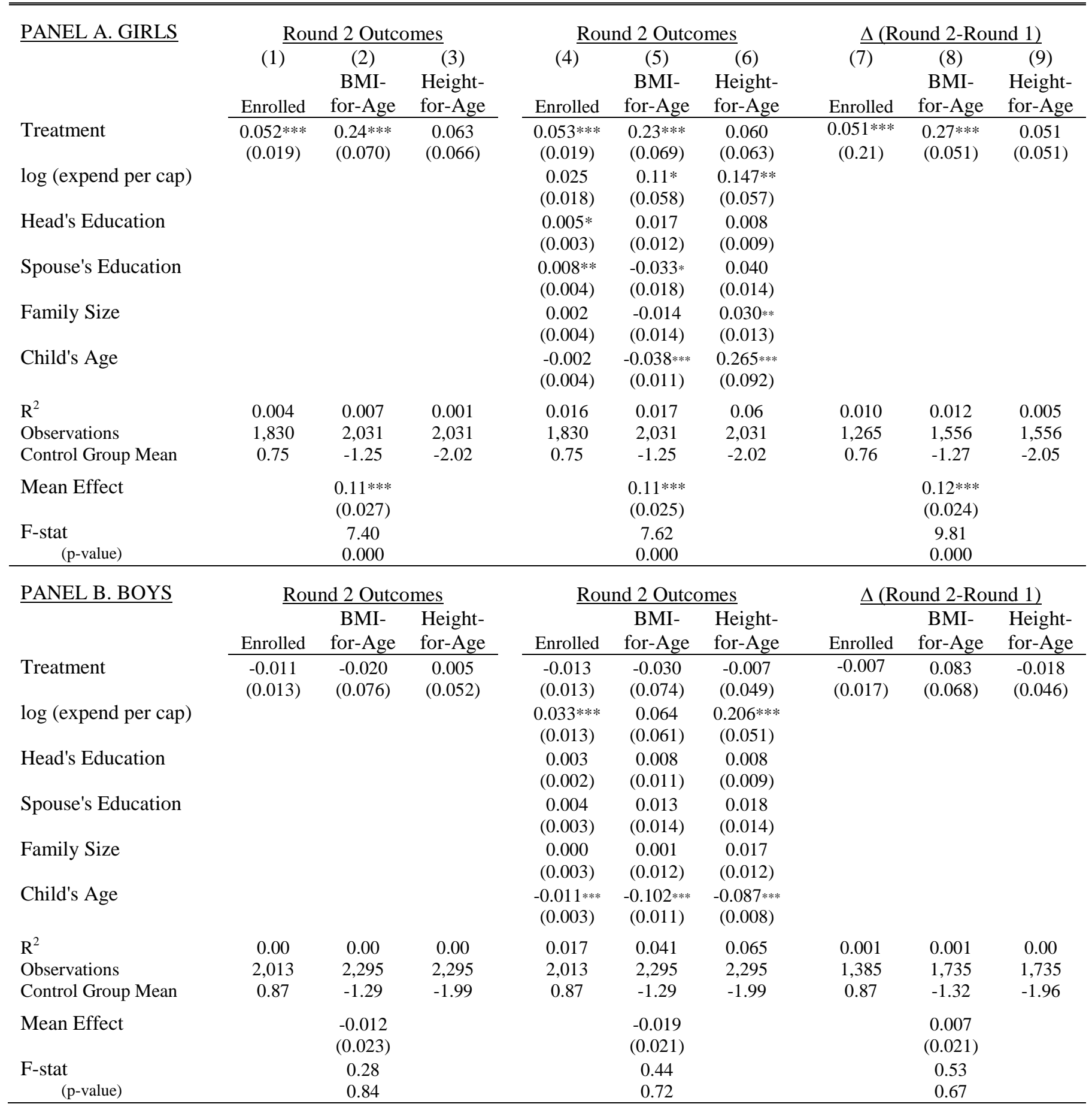

Notes: Heteroskedasticity-consistent standard errors accounting for clustering at the village-level in parentheses. Columns 1-6 use Round 2 outcomes as the dependent variable, and Columns 7-9 use the change in outcome from Round 1 to Round 2 . For the first 6 columns, the sample is children aged 7-15 for schooling and 5-15 for BMI and height. For the first columns, the sample is children aged 5-12 at baseline (8-15 at round 2). BMI- and Height-for Age are z-scores. All control variables in columns 1-6 are measured in Round 2. All regressions also include indicators for whether expenditure or mother's or father's education data was unavailable (these household are assigned median values for these variables). "Mean effect" is the mean effect of the treatment across the three outcomes for a given specification, computed using the methodology described in Kling, Liebman, and Katz (2007). F-stat is from a joint test that the treatment variable is zero in the three specifications. *Significant at 10 percent level. **Significant at 5 percent level. ***Significant at 1 percent level. 


\begin{tabular}{|c|c|c|c|c|c|c|c|c|c|}
\hline \multirow[t]{2}{*}{$\underline{\text { PANEL A. GIRLS }}$} & \multicolumn{3}{|c|}{$\underline{\text { Round } 2 \text { Outcomes }}$} & \multicolumn{3}{|c|}{ Round 2 Outcomes } & \multicolumn{3}{|c|}{$\Delta($ Round 2-Round 1) } \\
\hline & $\begin{array}{c}\text { (1) } \\
\text { Enrolled }\end{array}$ & $\begin{array}{c}(2) \\
\text { BMI- } \\
\text { for-Age }\end{array}$ & $\begin{array}{c}(3) \\
\text { Height- } \\
\text { for-Age }\end{array}$ & $\begin{array}{c}\text { (4) } \\
\text { Enrolled }\end{array}$ & $\begin{array}{c}(5) \\
\text { BMI- } \\
\text { for-Age }\end{array}$ & $\begin{array}{c}(6) \\
\text { Height- } \\
\text { for-Age }\end{array}$ & $\begin{array}{c}\text { (7) } \\
\text { Enrolled }\end{array}$ & $\begin{array}{c}(8) \\
\text { BMI- } \\
\text { for-Age }\end{array}$ & $\begin{array}{c}(9) \\
\text { Height- } \\
\text { for-Age }\end{array}$ \\
\hline $\log$ (expend per cap) & & & & $\begin{array}{c}0.023 \\
(0.018)\end{array}$ & $\begin{array}{l}0.101 * \\
(0.057)\end{array}$ & $\begin{array}{c}0.140 * * \\
(0.055)\end{array}$ & & & \\
\hline Spouse's Education & & & & $\begin{array}{c}0.009 * * \\
(0.004)\end{array}$ & $\begin{array}{l}-0.032 * \\
(0.017)\end{array}$ & $\begin{array}{c}0.037 * * * \\
(0.014)\end{array}$ & & & \\
\hline Family Size & & & & $\begin{array}{c}0.004 \\
(0.004)\end{array}$ & $\begin{array}{l}-0.011 \\
(0.013)\end{array}$ & $\begin{array}{c}0.032 * * \\
(0.012)\end{array}$ & & & \\
\hline Child's Age & & & & $\begin{array}{l}-0.003 \\
(0.004)\end{array}$ & $\begin{array}{c}-0.041 * * * \\
(0.010)\end{array}$ & $\begin{array}{c}-0.083^{\text {**** }} \\
(0.009)\end{array}$ & & & \\
\hline Mean Effect & & $\begin{array}{c}0.059 * * \\
(0.026)\end{array}$ & & & $\begin{array}{c}0.060 * * \\
(0.025)\end{array}$ & & & $\begin{array}{c}0.070 * * \\
(0.027)\end{array}$ & \\
\hline $\begin{array}{l}\text { F-stat } \\
\quad(p \text {-value })\end{array}$ & & $\begin{array}{c}2.88 \\
0.038 \\
\end{array}$ & & & $\begin{array}{c}3.01 \\
0.032 \\
\end{array}$ & & & $\begin{array}{c}3.07 \\
0.030 \\
\end{array}$ & \\
\hline PANEL B. BOYS & $\underline{\text { Rol }}$ & nd 2 Outc & mes & $\underline{\text { Rol }}$ & nd 2 Outce & mes & $\Delta(\mathrm{R}$ & and 2-Ro & nd 1) \\
\hline & Enrolled & $\begin{array}{c}\text { BMI- } \\
\text { for-Age }\end{array}$ & $\begin{array}{l}\text { Height- } \\
\text { for-Age }\end{array}$ & Enrolled & $\begin{array}{c}\text { BMI- } \\
\text { for-Age }\end{array}$ & $\begin{array}{l}\text { Height- } \\
\text { for-Age }\end{array}$ & Enrolled & $\begin{array}{c}\text { BMI- } \\
\text { for-Age }\end{array}$ & $\begin{array}{l}\text { Height- } \\
\text { for-Age }\end{array}$ \\
\hline Treatment & $\begin{array}{c}-0.029 * * \\
(0.013)\end{array}$ & $\begin{array}{c}-0.09 \\
(0.073)\end{array}$ & $\begin{array}{l}-0.061 \\
(0.050)\end{array}$ & $\begin{array}{c}-0.030^{* *} \\
(0.013)\end{array}$ & $\begin{array}{l}-0.097 \\
(0.072)\end{array}$ & $\begin{array}{c}-0.066 \\
(0.047)\end{array}$ & $\begin{array}{l}-0.021 \\
(.017)\end{array}$ & $\begin{array}{l}-0.029 \\
(0.064)\end{array}$ & $\begin{array}{l}-0.064 \\
(0.044)\end{array}$ \\
\hline $\log$ (expend per cap) & & & & $\begin{array}{c}0.028 * * \\
(0.013)\end{array}$ & $\begin{array}{c}0.063 \\
(0.059)\end{array}$ & $\begin{array}{c}0.196 * * * \\
(0.049)\end{array}$ & & & \\
\hline $\mathrm{R}^{2}$ & 0.002 & 0.001 & 0.001 & 0.017 & 0.042 & 0.066 & 0.001 & 0.001 & 0.001 \\
\hline Observations & 2,047 & 2,388 & 2,388 & 2,047 & 2,388 & 2,388 & 1,403 & 1,851 & 1,828 \\
\hline Mean Effect & & $\begin{array}{c}-0.061 * * * \\
(0.023)\end{array}$ & & & $\begin{array}{c}-0.066 * * * \\
(0.021)\end{array}$ & & & $\begin{array}{c}-0.049 * * \\
(0.023)\end{array}$ & \\
\hline $\begin{array}{l}\text { F-stat } \\
\quad(p \text {-value) }\end{array}$ & & $\begin{array}{c}3.10 \\
0.028 \\
\end{array}$ & & & $\begin{array}{c}3.95 \\
0.009 \\
\end{array}$ & & & $\begin{array}{l}1.62 \\
0.19 \\
\end{array}$ & \\
\hline
\end{tabular}

Notes: Heteroskedasticity-consistent standard errors accounting for clustering at the village-level in parentheses. Columns 1-6 use Round 2 outcomes as the dependent variable, and Columns 7-9 use the change in outcome from Round 1 to Round 2. For the first 6 columns, the sample is children aged 7-15 for schooling and 5-15 for BMI and height. For the first columns, the sample is children aged 5-12 at baseline (8-15 at round 2). BMI- and Height-for Age are z-scores. All control variables in columns 1-6 are measured in Round 2. All regressions also include indicators for whether expenditure or mother's or father's education data was unavailable (these household are assigned median values for these variables). "Mean effect" is the mean effect of the treatment across the three outcomes for a given specification, computed using the methodology described in Kling, Liebman, and Katz (2007). F-stat is from a joint test that the treatment variable is zero in the three specifications. *Significant at 10 percent level. **Significant at 5 percent level. ***Significant at 1 percent level. 
TABLE V. EFFECT OF THE INTERVENTION: TESTING ALTERNATE HYPOTHESES

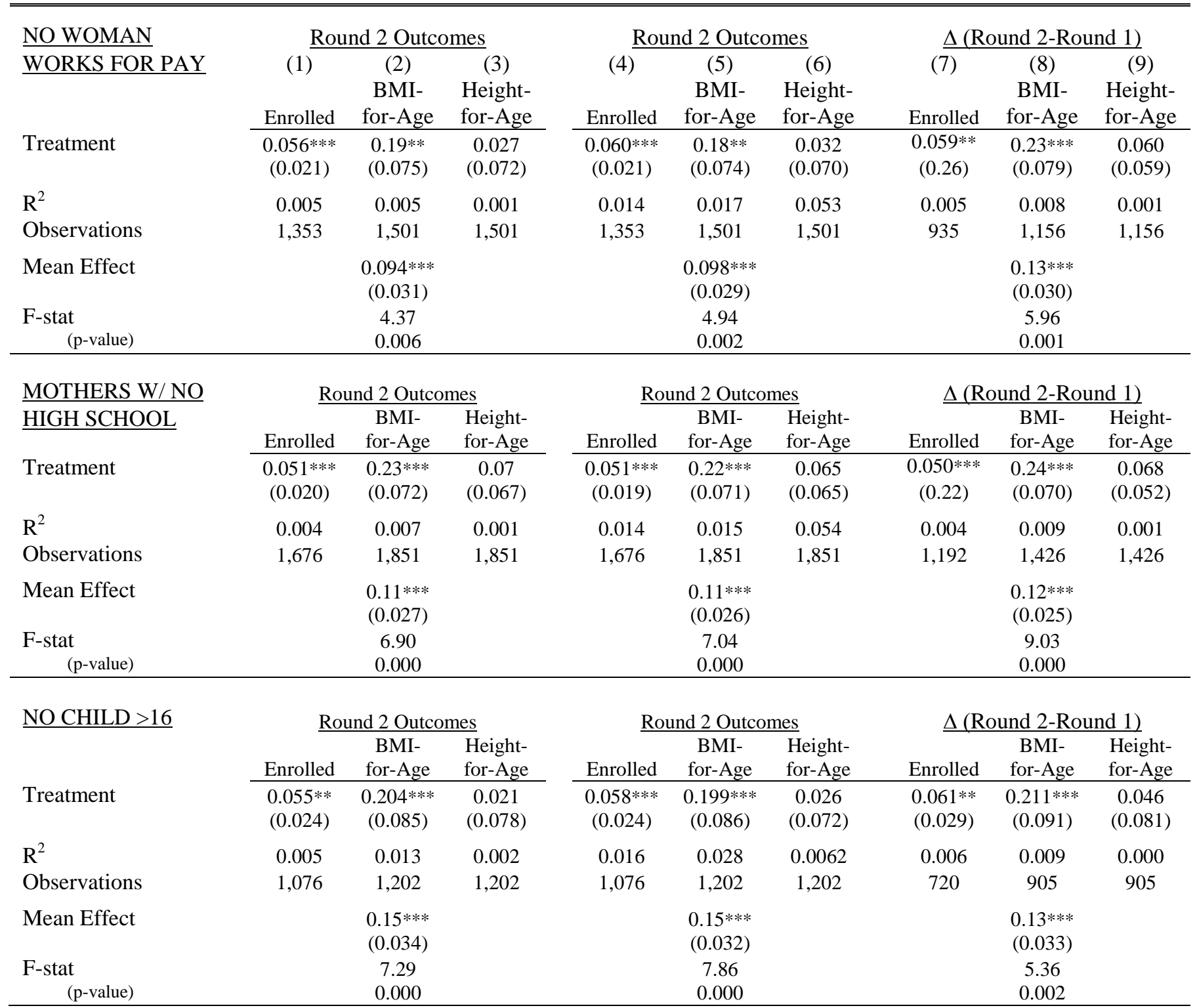

Notes: Heteroskedasticity-consistent standard errors accounting for clustering at the village-level in parentheses. Columns 1-6 use Round 2 outcomes as the dependent variable, and Columns 7-9 use the change in outcome from Round 1 to Round 2. For the first 6 columns, the sample is children aged 7-15 for schooling and 5-15 for BMI and height. For the first columns, the sample is children aged 5-12 at baseline (8-15 at round 2). BMI- and Height-for Age are z-scores. All control variables in columns 1-6 are measured in Round 2. All regressions also include log expenditure per capita, head's and spouse's education, family size, child age, and indicators for whether expenditure or mother's or father's education data was unavailable (these household are assigned median values for these variables). "Mean effect" is the mean effect of the treatment across the three outcomes for a given specification, computed using the methodology described in Kling, Liebman, and Katz (2007). F-stat is from a joint test that the treatment variable is zero in the three specifications. *Significant at 10 percent level. **Significant at 5 percent level. ***Significant at 1 percent level. 